\title{
Germination Characters as Affected by Salinity Stress and Soaking Grain Sorghum Genotypesin Humic acid
}

\author{
Kandil A.A. ${ }^{1}$, A.E. Sharief ${ }^{1 *}$, Doha E. A. Elbadry ${ }^{2}$ \\ ${ }^{1}$ Agronomy Department, Faculty of Agriculture, Mansoura University, Egypt \\ ${ }^{2}$ Ministry of Agriculture, Egypt \\ *Corresponding Author
}

\begin{abstract}
In order to investigate salinity stress on sorghum germination indices, an experiment conducted in the Faculty of Agriculture, Mansoura University from June and July 2017 in Agronomy Department, Seed Science Laboratory. The goals of the investigation aimed to screening for five (Sorghum bicolor L.(Moench) cultivarsviz. Dorado, hybrid 306, Giza 15, Mecca hybrid and $\mathrm{H}-305$ under salinity stress, sodium chloride $(\mathrm{Na} \mathrm{Cl})$ at the levels of 0 (as control), 3, 6, 9, 12 and $15 \mathrm{dS} / \mathrm{m}^{-1}$ and soaking in humic acid. The results showed that soaking seed in humic acid exceeded percentage of germination, germination rate, germination index, energy of germination and chlorophyll content by 5.2, 7.7, 17.1, 65.8 and $17.8 \%$, respectively. The highest germination percentage (91.9 \%), germination rate (3.08), germination energy (59.7), seedling vigor index (1483.7) and chlorophyll content (2.88) were obtained from sown Mecca hybrid. The maximum germination index (117.22) was obtainedfrom sown Giza 15 cultivar.The results point out that cumulative salinity level from 3 to $15 \mathrm{dSm}$ ${ }^{1}$ condensedall studied germination characters. Accumulative salinity levels to $15 \mathrm{dSm}^{-}$ ${ }^{1}$ condensedpercentage of germination, germination rate, index of germination, germination energy and seedling vigor index by 15.9, 15.0, 30.0, 35.9 and $37.6 \%$, respectively compared without salinity application. It could recommended that soaking sorghum seed of Meeca hybrid with humic acid for $12 h$ under salinity of concentration of $6 \mathrm{dSm}^{-1}$ enhanced germination characters compared with other cultivars and salinity concentrations, it mean cultivated it under reclaimed saline soil in Egypt.
\end{abstract}

Keywords - Salinity Stress, Genotypesin Humic acid, Mansoura University.

\section{INTRODUCTION}

Sorghum is one of the most important staple food crops especially in the drier and smaller areas of the semi-arid Tropics of Africa (Ali et al. 2011).Salinity is adversely affecting crop yield of crops to various extents of Egypt and the World. To overcome the shortage of cereal productivity. It could have achieved by growing grain sorghum cultivars tolerant of salinity to get economical yields from saline reclaimed soils, particularly in early seedling stages is very important. Soil salinization is a great determinate factor of crop productivity, especially in dried area (Ahmed, 2009).Many physiological variations are induced germination percentage and affecting seedling growth and development(Saroj and Soumana, 2014).

Seed germination positively affected by humic acid soaking and resulted more root length. Germination testes using various levels of humic extract, the doses higher than $20 \% \mathrm{v} / \mathrm{v}$ repressed seed germination (Asenjo et al., 2000).Extraof $90 \%$ from seeds germinated after five days with soaking of 100-ppm potassium humate, for 24 hours (Ali and Elbordiny, 2009). Wheat seed primed with humic enhanced the germination and produced higher germination\% as compared to that soakedin water (Ali et al., 2014). The highest percentage of germination gone to Sepideh cultivar and the less percentages of germination fitted to Payam cultivar under stress conditions (Mohammadi and Mojaddam, 2014). The inhibiting effect of salt on the seed germination improved in variable degrees by pretreatment of humic acid(Çavuşoğlu and Ergin, 2015).

The recommended cultivar for new reclaimed saline soils were Soavecultivar (Almodares et al., 2007). Genotypes of 235461 and 69239recorded the less germination rate and the great percentages of germination (Geressu and Gezahagne, 2008). Delay in germination time due to salinity stress. Maximum germination percentage produced from KFS4 cultivar (Aishah et al., 2010). Genotypes differed from salt sensitive to germination percentage(Asfaw, 2011).Sorghum genotypes differed from response to salinity, the medium tolerant recorded by cultivars of Hegari and JS-263, while the less sensitive produced from Noor cultivar and the sensitive produced from FJ-115 and PSV-4 cultivars(Kausar et al., 2012). The STI, GMP and MP genotypes were better to 
cultivate salinity and unsolidity stress(Hefny et al., 2013). The highest germination percentage recorded from Meko, Gambella1107, ICSV-111 and Melkam varieties and were more salt tolerant cultivars. However, ESH-2 and Go bye varieties were salt sensitive. The rest sorghum varieties were middle in their salt tolerance (Tigabo et al., 2013). Sown Shallu, Desert Maize, and 1790E genotypes graded the most salt tolerant cultivars, while the least salt tolerance genotypes produced from Schrock and RTx430 cultivars(Sun et al., 2014).

Salinity at a rate of $300 \mathrm{mM}$, the time of germination of CSF 18 variety increased, but germination speed and germination test variables decreased. The CSF 20 variety was in the same trend, except for the speed germination and the time of germination, which influenced by sodium chloride at the $150 \mathrm{mM}$ level. The CSF 18 variety had more tolerance to salinity than CSF 20 variety during the germination stage(De oliveir and Gomes-Filho, 2009). The percentage of germination increased from thelowest level of salinity $\left(2 \mathrm{dS} / \mathrm{m}^{-1}\right)$, while inhibited the germination \% atsalinity levels of 4,8 and $16 \mathrm{dS} / \mathrm{m}^{-1}$. Wad Ahmed cultivar recorded the more salt tolerant, but Arfagadamak and Butana cultivars were the more salt sensitive (El Naim et al., 2012). The germination percentage decreased with salinity concentrations increased. The lowest germination percentage produced from CSV-15 and Pant-1 cultivars at highest salinity level(Chauhan et al., 2012).KFS2, KFS4 genotypes produced the highest rate of germination. LFS56 genotype recorded the lowest rate of germination by the 10\% (Tabatabaei and Anagholi, 2012). SSV84 cultivar recorded the highest salt tolerant variety and the highest percentage of germination produced from IS6973 cultivar (Almodares et al., 2014).A significant reduced from germination characteristics of sorghum triggered by salinity.The percentage of germination, germination rate and time of germination were decreased with salinity concentration increased (Behzadnejad and Tohidinejad, 2014). The rate of germination and germination percentage decreased as salinity levels increased. Germination parameters were the lowest at salinity level of 9 and $12 \mathrm{dS} / \mathrm{m}^{-1}$ (Dadar et al., 2014).Seed germination reduced at $1.5 \% \mathrm{NaCl}$ treatment. Germinating percentage reduced by $35.8 \%$ in higher salt concentrations (Sam et al., 2014). The lessening connected to the salinity rate of
$12 \mathrm{dS} / \mathrm{m}^{-1}$ betweensorghum genotypes, the greatest in terms of germination parameters were Kimia, Sepideh, and Payam genotypes. Salinity stress significantly influencedmost germination traits and reduced the germination related the same characters (Sawamery and Mojaddam, 2014). The highest percentage of germination produced from the control, but the lowest onesobtained from $1.5 \%$ salinity level. The sensitive cultivar to salinity produced from Barbarei cultivars compared to Tabat and Wad-Ahmed cultivars, Tab at cultivar was recorded themost- salt tolerant cultivars (Siddig and Idris, 2015).Therefore, the goals of this exploration intended to study the performance of seed viability of studied sorghum cultivars under salinity stresses.

\section{MATERIALS AND METHODS}

\subsection{Treatments and Experimental Design:}

A laboratory experiment carried out in the Faculty of Agriculture, Mansoura University from June 2017 to July 2017 in Agronomy Department, Seed Science Laboratory. The aimed of the investigation conducted to screening forfive (Sorghum bicolor L.(Moench) cultivars i.e. Dorado, hybrid 306, Giza 15, Mecca hybrid and H-305 under salinity stress, $\mathrm{Na} \mathrm{Cl}$ at the levels of 3, 6,9, 12 and $15 \mathrm{dS} / \mathrm{m}^{-1}$ beside the control, soaked or non-soaked in humic acid.The conducted experimentwas assignedto factorial experiment in RCBDin four replication. The first factorcontain two treatments with and without soaking in humic acid. The second factor includesthe five-grain sorghum cultivars i.e. Dorado, hybrid 306, Giza 15, Mecca hybrid and H-305 obtained from ARC Ministry of Agriculture. The third factor contained withinfive different levels of $\mathrm{NaCl}$ include $0,3,7,11$ and $15 \mathrm{dS} / \mathrm{m}^{-1}$. The experiment comprised 240Petri dishes assigned in factorial experiment of Randomized Complete Block Design (RCBD). Then, the Petri dishes placed in a growth chamber for 14 days at $28 \pm \mathrm{C}^{\mathrm{o}}$ for germination according to ISTA, 2013 roles.

\subsection{Studied characters:}

The studied of germination parameters as follows:

1-The final percentage of germination (FGP):Thepercentage of germination from total calculated after 14 days from sowing following by Ellis and Roberts, (1981) and Ruan et al., (2002)equation:

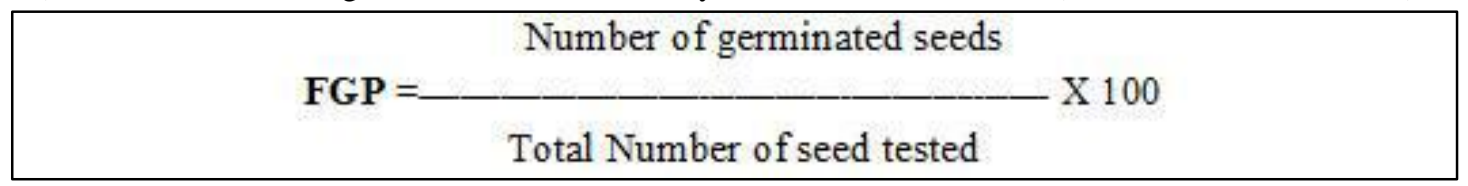

2-The germination rate (GR) wasintendedconferring to the following equation by(Ellis and Roberts 1981).

$$
\text { Number of germinated seeds }
$$

$$
\mathbf{G R}=\frac{\text { Number of germination days }}{\text { Num }}
$$


3-The germination index (GI) was calculated according to Karim et al. (1992)equation.

GI $=\frac{\% \text { Germination in each treatment }}{\% \text { Germination in the control }} \times 100$

4-The energy of germination (EG) was measured according toRuan et al., (2002).

$\mathbf{E C}=\frac{\text { Number of germinated seeds after four days }}{\text { Number of germination days }} \times 100$

5-Average of seedling vigor index (SVI)was measured according toAbdel Baki and Anderson (1970)formula.

$$
\text { SVI }=(\text { Average shoot length }+ \text { Average root length }) \text { X Germination } \%
$$

6-Total chlorophyll (SPAD): Average of total chlorophyll (SPAD) in seedling leaf samples assessed by SPAD-502 (Minolta Co. Ltd., Osaka, Japan).

\subsection{Statistical Analysis:}

According to the technique of variance (ANOVA) for the factorial in RCBD as published by Gomez and Gomez (1991)of the subjected data was statistically analyzed.LSDmethod was used as defined by Snedecor and Cochran (1980) the.The data analyzed statisticallyin RCBD design by MSTAT-C computer package as described by Russel (1986).

\section{RESULTS AND DISCUSSIONS}

\subsection{Humic acid soaking effect:}

The results presented in Table (1) clearly showed that soaking in humic acid significantly affected studied germination parameters and chlorophyll content, except seedling vigor index insignificantly affected. Soaking seed in humic acid exceeded germination $\%$, germination rate, germination index, energy of germination and chlorophyll content by 5.2, 7.7, 17.1, 65.8 and $17.8 \%$, respectively. Extra of $90 \%$ from seeds germinated after five days with soaking of 100-ppm potassium humate, for 24 hours (Ali and Elbordiny, 2009). Priming of wheat seed with humic produced higher percent seed germination as compared to priming seeds in alone water (Ali et al., 2014).

\subsection{Cultivars performance:}

The outcomes of statistical analysis was presented in Table (1) clearly revealed that studied sorghum cultivars significantly affected studied germination parameters and chlorophyll content. The highest germination percentage $(91.9 \%)$, germination rate (3.08), energy of germination (59.7), seedling vigor index (1483.7) and chlorophyll content (2.88) were obtained from sown Mecca hybrid. The highest germination index (117.22) was produced from sown Giza 15 cultivar. However, the lowest germination percentage $(40.8 \%)$, germination rate $(1.35)$, germination index (77.97), energy of germination (15.9) and seedling vigor index (481.9). While, the lowest chlorophyll content (2.20) was produced from sown Dora cultivar. The recommended cultivar was Soave for soils with high salinity (Almodares et al., 2007). NM-92 cultivar was more adaptability under saline conditions (Ahmed, 2009). The time of germination of CSF 18 variety increased at salinity of $300 \mathrm{mM}$, but the speed of germination and germination test variables decreased. The CSF 20 variety was in the same trend, except for the speed germination and the time of germination, which influenced by $\mathrm{NaCl}$ at the $150 \mathrm{mM}$ level. The CSF 18 variety had better tolerance to salt stress during the germination stage than CSF 20 (De oliveir and GomesFilho, 2009). Deferral in germination time related to salinity, the highest germination percentage produced from KFS4 cultivar (Aishah et al., 2010). Genotypes differed from salt sensitive to germination percentage (Asfaw, 2011). The percentage of germination increased from the lowest level of salinity $\left(2 \mathrm{dS} / \mathrm{m}^{-1}\right)$, while inhibited the germination percentage of salinity levels of 4, 8 and $16 \mathrm{dS} / \mathrm{m}^{-1}$. Wad Ahmed cultivar recorded the more salt tolerant, but Arfagadamak and Butana cultivars were the more salt sensitive (El Naim et al., 2012). The more tolerant of salinity stress produced from Hoars cultivar followed by Mabrouk cultivar, which will cultivate under new reclaimed saline soils (Kandil, et al., 2012). Germination percentage was clearly demonstrated varietal differences (Khan et al., 2014).

\subsection{Salinity level effects:}

The outcomes of statistical analysis was presented in Table (1) clearly revealed that salinity concentration significantly affected studied germination parameters, except chlorophyll content insignificantly affected. The results indicated that increasing salinity concentration from 3 to $15 \mathrm{dSm}^{-1}$ significantly condensed the percentage of germination, and germination rate, germination index, energy of germination and seedling 
vigor index. The highest germination percentage (73.7 $\%)$, germination rate (2.46), germination index (122.5), energy of germination (52.0) and seedling vigor index (1166.8) were produced from the control treatment. However, the lowest percentage of germination $(62.0 \%)$, germination rate (2.09), germination index (85.26), energy of germination (33.3) and seedling vigor index (727.9) were produced from the highest salinity concentration of $15 \mathrm{dSm}^{-1}$. Increasing salinity concentration to $15 \mathrm{dSm}^{-1}$ significantly decreased germination (\%), germination rate, germination index, energy of germination and seedling vigor index by 15.9 , 15.0, 30.0, 35.9 and $37.6 \%$, respectively compared with the control treatment. It exercises an adverse effect of osmotic inhibition and ionic toxicity (Munns et al., 2006).

Table.1: Averages of percentage of germination, and germination rate, germination index, energy of germination, seedling vigor index and chlorophyll content as affected by humic acid soaking, sorghum cultivars and salinity concentrations.

\begin{tabular}{|c|c|c|c|c|c|c|}
\hline Treatment & $\begin{array}{c}\text { Germination } \\
\text { percentage }\end{array}$ & $\begin{array}{l}\text { Germination } \\
\text { rate }\end{array}$ & $\begin{array}{l}\text { Germination } \\
\text { index }\end{array}$ & $\begin{array}{c}\text { Energy of } \\
\text { germination }\end{array}$ & $\begin{array}{l}\text { Seedling vigor } \\
\text { index }\end{array}$ & $\begin{array}{c}\text { Chlorophyll } \\
\text { content }\end{array}$ \\
\hline \multicolumn{7}{|l|}{ A. Humic acid: } \\
\hline Without & 65.7 & 2.17 & 86.80 & 20.9 & 924.7 & 2.40 \\
\hline Soaking & 69.3 & 2.35 & 104.76 & 60.0 & 965.1 & 2.92 \\
\hline F-test & $*$ & $*$ & $*$ & $*$ & NS & $*$ \\
\hline \multicolumn{7}{|c|}{ B. Sorghum cultivars: } \\
\hline Dora & 63.1 & 2.12 & 89.05 & 47.6 & 759.0 & 2.20 \\
\hline H.306 & 53.2 & 1.75 & 96.58 & 25.1 & 712.2 & 2.51 \\
\hline Giza 15 & 89.1 & 3.00 & 117.22 & 53.9 & 1287.7 & 3.24 \\
\hline Mecca hybrid & 91.9 & 3.08 & 98.09 & 59.7 & 1483.7 & 2.88 \\
\hline H-305 & 40.8 & 1.35 & 77.97 & 15.9 & 481.9 & 2.49 \\
\hline F-test & * & $*$ & * & $*$ & $*$ & $*$ \\
\hline L.S.D 5\% & 4.6 & 0.16 & 25.11 & 4.2 & 97.8 & 0.41 \\
\hline \multicolumn{7}{|c|}{ C. Salinity concentrations: } \\
\hline $0 \mathrm{dsm}^{-1}$ & 73.7 & 2.46 & 122.50 & 52.0 & 1166.8 & 2.64 \\
\hline $3 \mathrm{dsm}^{-1}$ & 69.6 & 2.32 & 96.91 & 42.7 & 1098.9 & 2.90 \\
\hline $6 \mathrm{dsm}^{-1}$ & 68.2 & 2.31 & 94.92 & 40.7 & 986.2 & 2.85 \\
\hline $9 \mathrm{dsm}^{-1}$ & 66.6 & 2.22 & 89.15 & 36.1 & 854.5 & 2.48 \\
\hline $12 \mathrm{dsm}^{-1}$ & 65.2 & 2.17 & 85.97 & 38.1 & 835.2 & 2.63 \\
\hline $15 \mathrm{dsm}^{-1}$ & 62.0 & 2.09 & 85.26 & 33.3 & 727.9 & 2.49 \\
\hline F-test & $*$ & $*$ & $*$ & $*$ & $*$ & NS \\
\hline L.S.D 5\% & 5.1 & 0.17 & 27.51 & 4.6 & 107.19 & 0.45 \\
\hline
\end{tabular}

Percentage of germination and germination ratedecreased as salinity levels were increased (Jamil et al., 2006).Percentage of germination reduced and time of germination increased due salinity stress(Jajarmi. 2007). The germination percentage decreased with salinity concentrations increased. The lowest germination percentage produced from CSV-15 and Pant-1 cultivars at highest salinity level(Chauhan et al., 2012). The KFS2 and KFS4 varieties produced the maximum rate of germination.. LFS56 variety showed the lowest rate of germination by the 10\% (Tabatabaei and Anagholi, 2012). Salt stress unfavorablydistressesseedling at germination stage (Hussain et al., 2013). These results from good agreement with those reported by Noreen and Ashraf (2008), Almodares et al. (2014), Behzadnejad and Tohidinejad (2014), Dadar et al. (2014) and Sam et al.(2014).

3.4. Interaction effects:
3.4.1. Interaction between humic acid soaking and cultivars effects:

Regarding to the interaction between humic acid soaking and studied sorghum cultivars, the results clearly revealed that this interaction significantly affected the moststudied germination parameters and chlorophyll content, however, germination index, insignificantly affected. The results graphically illustrated in Figs. 1, 2 and 4 indicated that highest germination percentage (96.33\%) and germination rate (3.20), seedling vigor index (1646.7) were produced from sownMecca hybrid when soaked with humic acid. In addition, energy of germination (92.83) and chlorophyll content (3.81) were obtainedfrom sown Giza 15 cultivar when soaked with humic acid as shown in Fig. 3 and 5. Whereas, the lowest germination percentage $(31.33 \%)$, energy of germination (5.50), seedling vigor index (375.46) were produced from sown Giza 15 cultivar without soaking in humic acid as shown 
in Figs 1, 3 and 4.In addition, the lowest values of chlorophyll content (1.93) was produced from sown Dora

cultivar without soaking in humic acid as shown in Fig. 5.

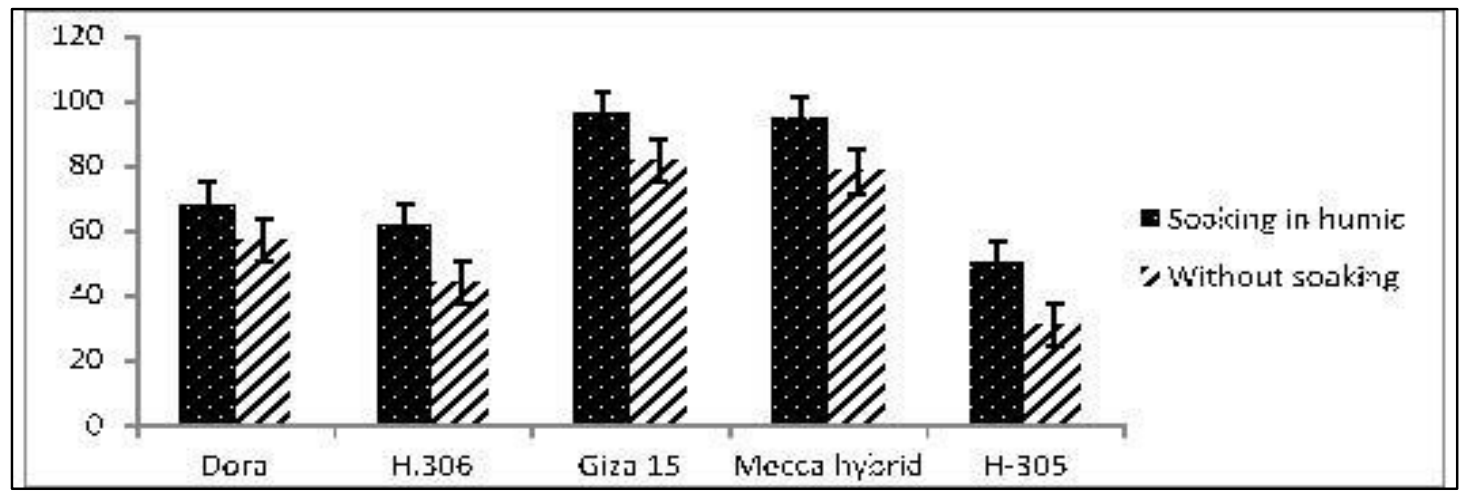

Fig.1. Average of percentage of germination as influencedby the interaction between humic acid soaking and studied sorghum cultivars.

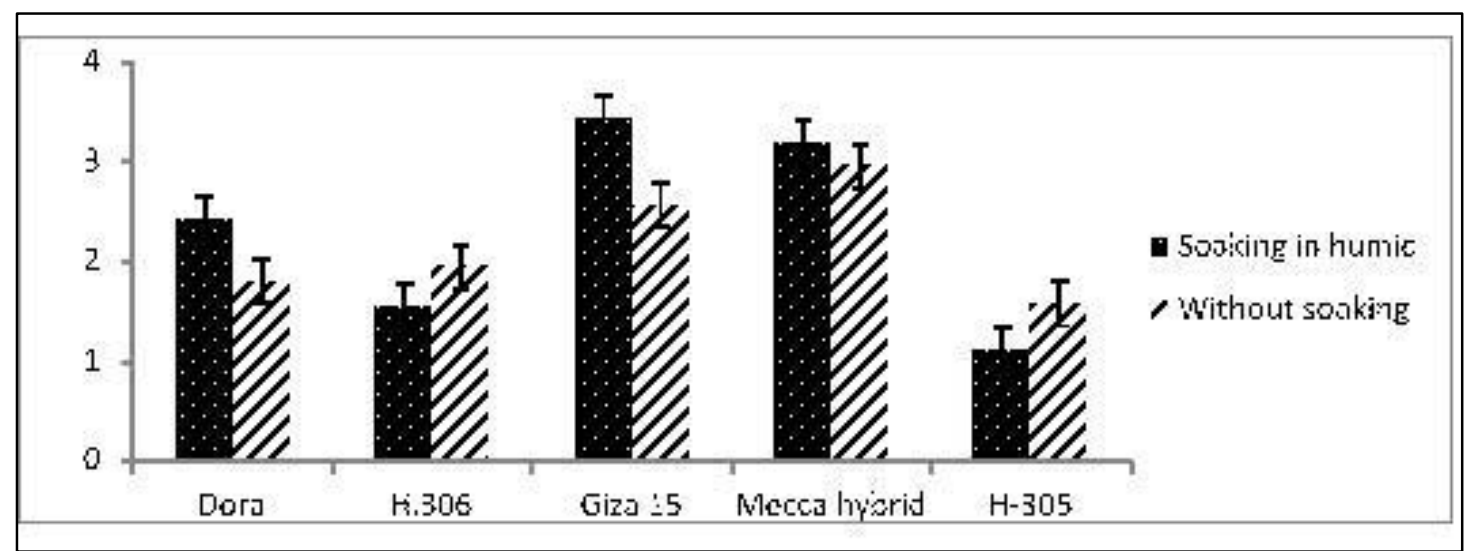

Fig.2: Average of germination rate as influenced by humic acid soaking and studied sorghum cultivars.

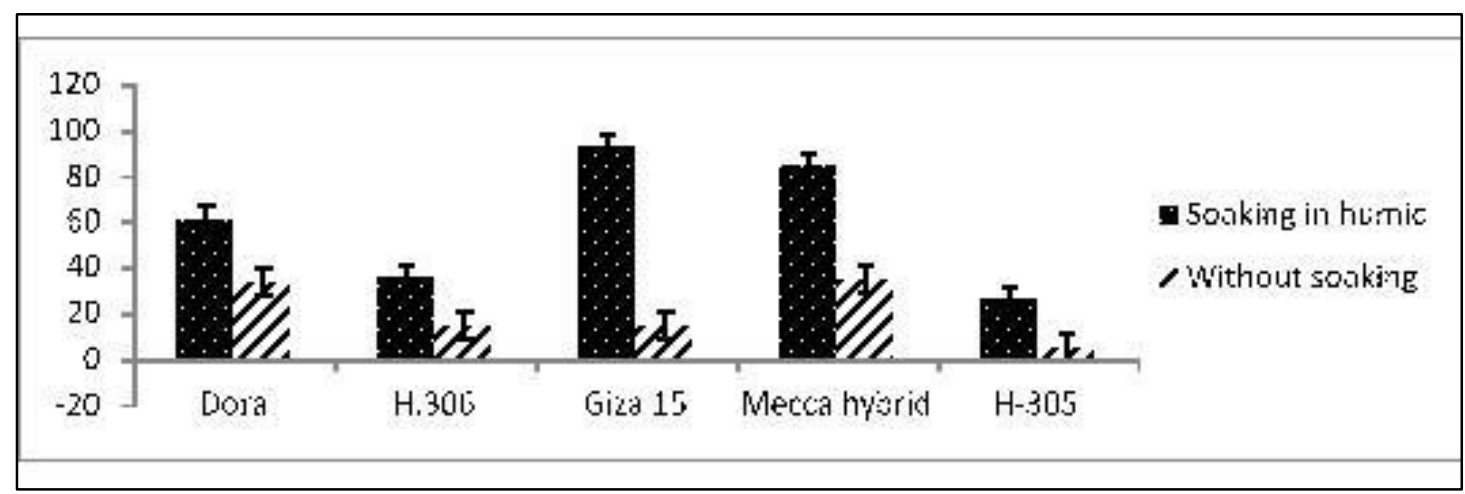

Fig.3: Averageof energy of germination as influenced by humic acid soaking and studied sorghum cultivars.

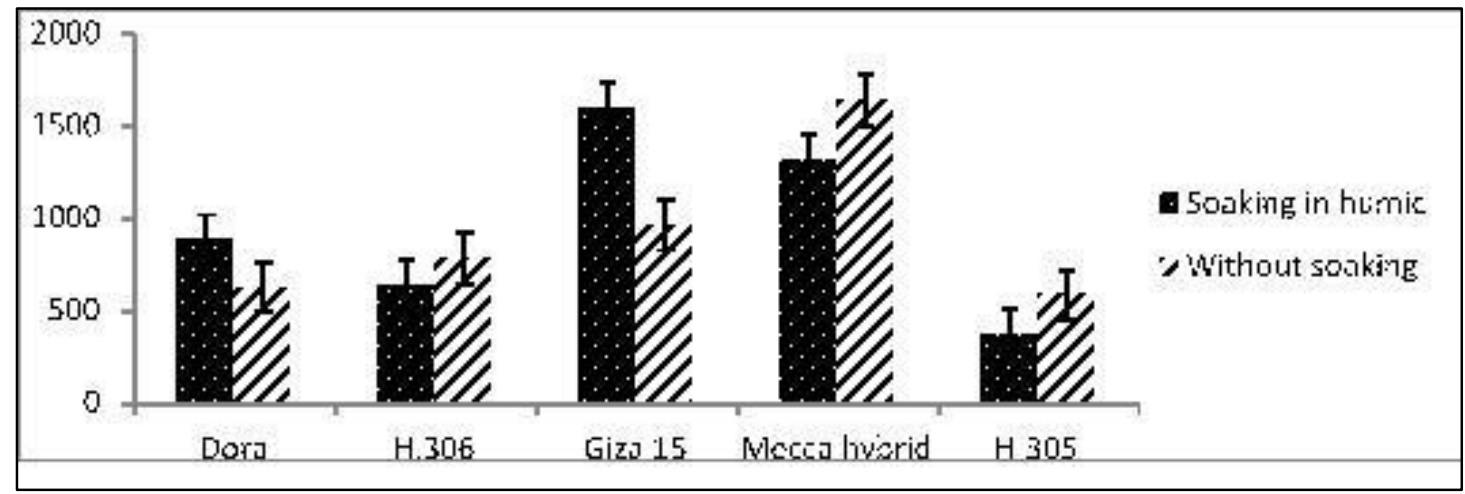

Fig.4: Average ofseedling vigor index as influenced by humic acid soaking and studied sorghum cultivars. 


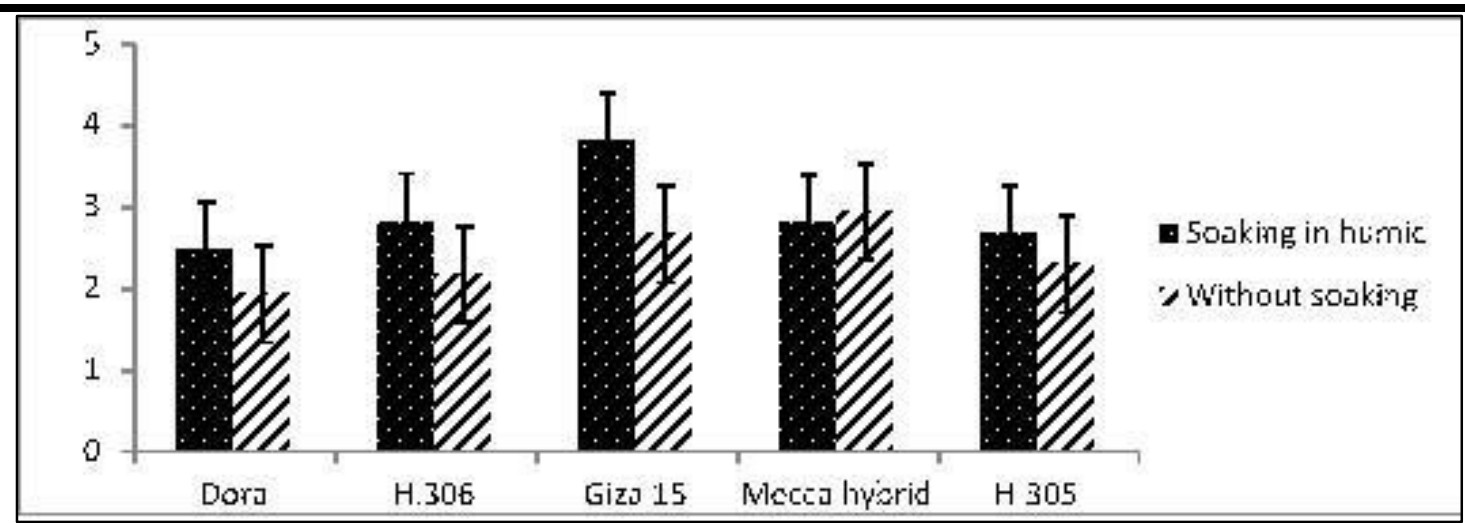

Fig.5: Average ofchlorophyll as influenced by humic acid soaking and studied sorghum cultivars.

Genotypes differed to salinity resistance level due to their different interactions with the salt ion and its concentrations (Wei and Qing-Xiang, 2011). The highest percentage of germination gone to Sepideh variety and the less percentage of germination went to Payam variety under stress conditions (Mohammadi and Mojaddam, 2014).

3.4.2. Interaction between humic acid and salinity levels effects:

Concerning to the interaction between humic acid soaking and salinity levels, the results clearly revealed that this interaction significantly affected the most studied germination parameters and chlorophyll content, however, insignificantly affected germination rate.The results graphically illustrated in Figs. 6,7, 8 and 9 indicated that highest germination percentage $(79.0 \%)$ and germination rate (2.48), energy of germination (63.6) seedling vigor index (1239.85) were produced from sown Mecca hybrid when soaked with humic acid.In addition,the highest values ofchlorophyll content (3.11) was produced from soaking seed in humic acid and salinity concentration of $3 \mathrm{dSm}^{-1}$ as shown in Fig 10 . However, the lowest germination percentage (58.2\%), germination rate (1.84), energy of germination (7.40), seedling vigor index (674.85) and chlorophyll content (2.20) were recorded from without soaking in humic acid at highest level of salinity of $15 \mathrm{dSm}^{-1}$ as shown in Figs. $6,7,8,9$ and 10 .

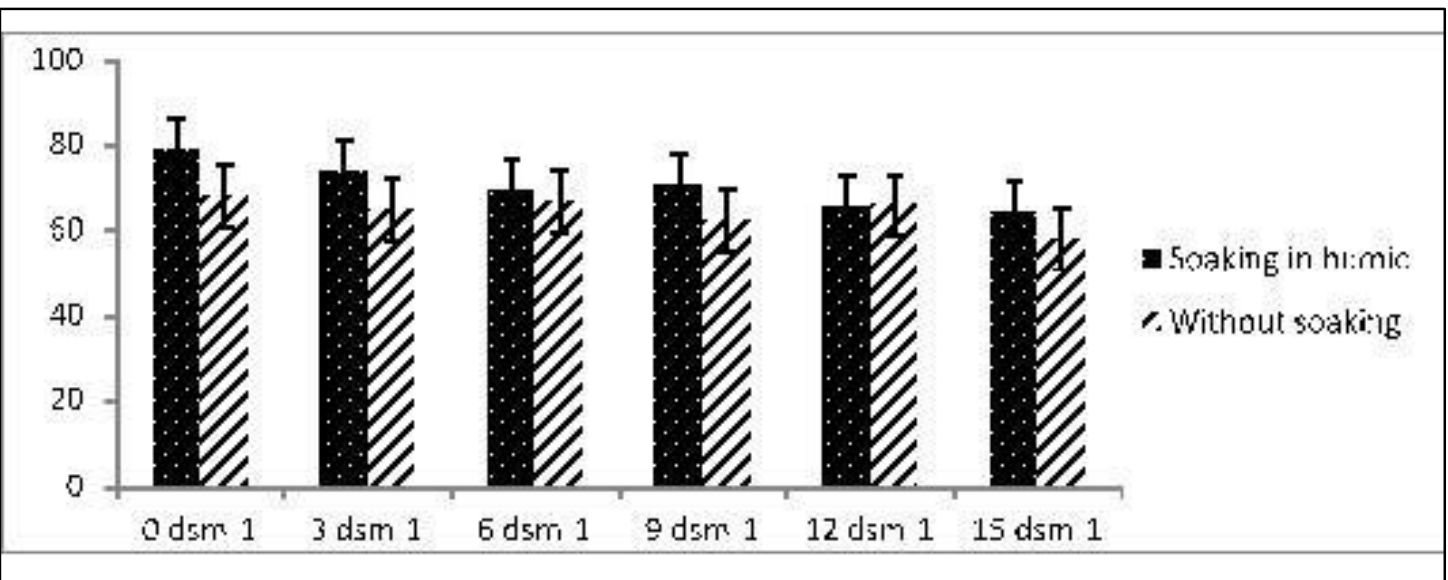

Fig.6: Average percentage of germination as influenced by humic acid soaking and salinity concentrations.

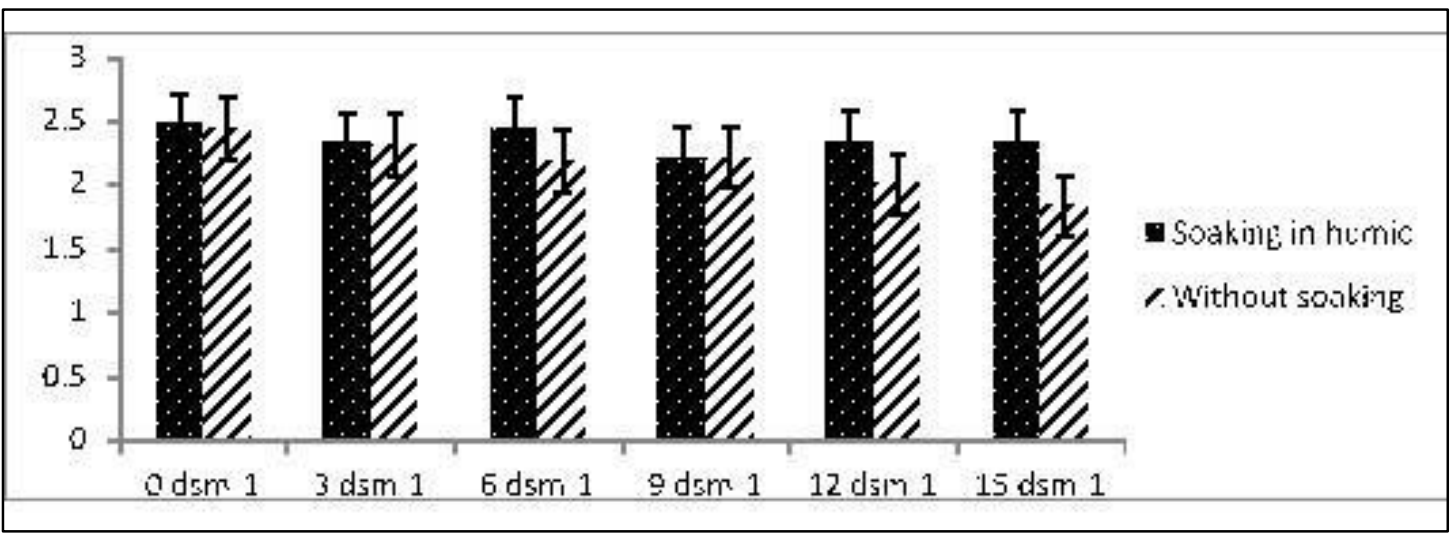

Fig.7: Average of germination rate as influenced by humic acid soaking and salinity concentrations. 
Sorghum genotypes differed from response to salinity, the medium tolerant recorded by genotypes of Hegariand JS263, while the intermediate sensitive produced from Noor cultivar and the sensitive produced from FJ-115 and PSV4 cultivars (Kausar et al., 2012). During germination of Meko, Gambella1107, ICSV-111 and Melkam varieties were extra salt tolerant. However, ESH-2 and Gobye varieties were salt sensitive. The respite varieties were midway in their salt tolerance (Tigabo et al., 2013). and the highest percentage of germination produced from IS6973 cultivar and moderate seedling characters and classified as moderate salt tolerant (Almodares et al., 2014). Inter cultivars genetic variation and concentration $\mathrm{x}$ cultivars interaction showed significant differences for all studied parameters (Khan et al., 2014). Similarly, many investigators such as Dadar et al. (2014), Sam et al. (2014), Sawamery and Mojaddam (2014), Siddig and Idris (2015) reported similar results. SSV84 cultivar recorded the highest salt tolerant variety

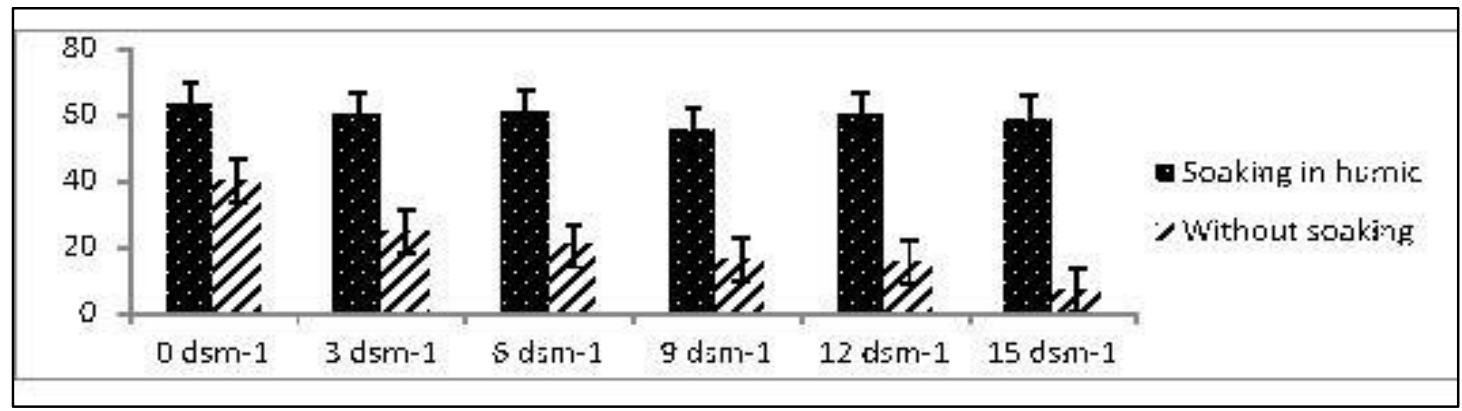

Fig.8: Average of energy of germination as influenced by humic acid soaking and salinity levels.

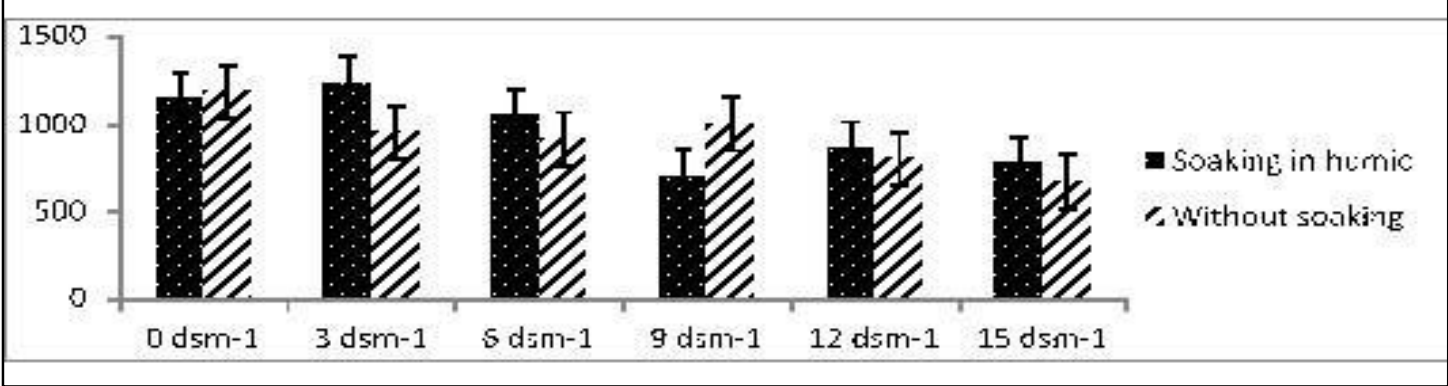

Fig.9: Average of seedling vigor index as influenced by humic acid soaking and salinity levels.

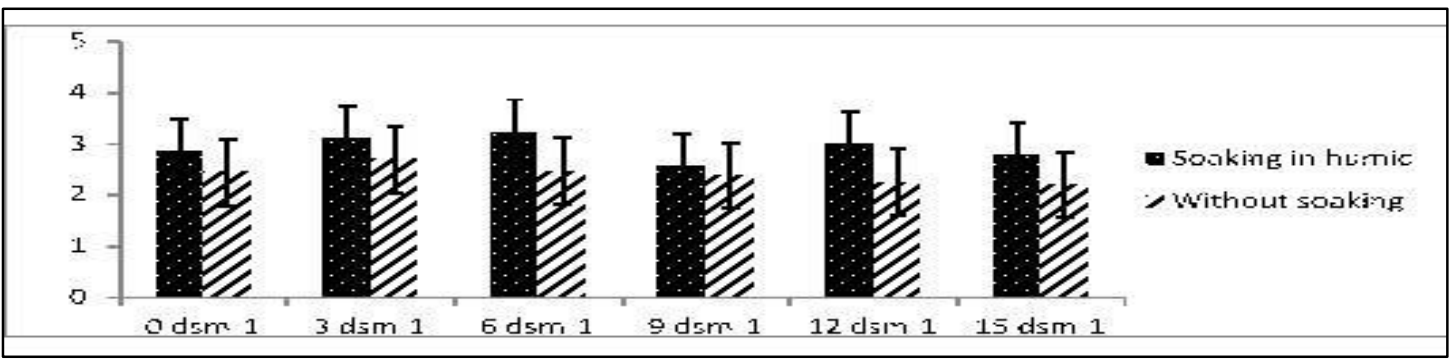

Fig.10: Average of chlorophyll as influenced by humic acid soaking and salinity levels

3.4.3. Interaction between studied sorghum and salinity levels effects:

Concerning to the interaction between studied sorghum and salinity levels, the results clearly revealed that this interaction significantly affected the most studied germination parameters and chlorophyll content insignificantly affected. The results graphically illustrated in Figs.11, 12 and 13 indicated that highest germination percentage $(92.0 \%)$, germination rate (3.06) and germination index (212.5) were recorded from sown Mecca hybrid at the control treatment. Where, the less percentage of germination $(28.5 \%)$, germination rate $0.96)$ and germination index (51.21) were produced from sown H-305 cultivar at highest salinity concentration of $15 \mathrm{dSm}^{-1}$ as shown in Figs.11, 12 and 13. The highest germination $(\%)$ went to Sepideh genotype and the lowest percentage of germination fitted to Payam genotype under stress conditions (Mohammadi and Mojaddam, 2014).Priming wheat seeds with PEG decreased percent seed germination of wheat compared to humic matters. Seed germination enhanced with humic acid soaking under drought stress(Nazi et al., 2014).The inhibiting effect of salt on the seed germination improved in variable degrees by pretreatment of humic acid (Çavuşoğlu and Ergin, 2015). 


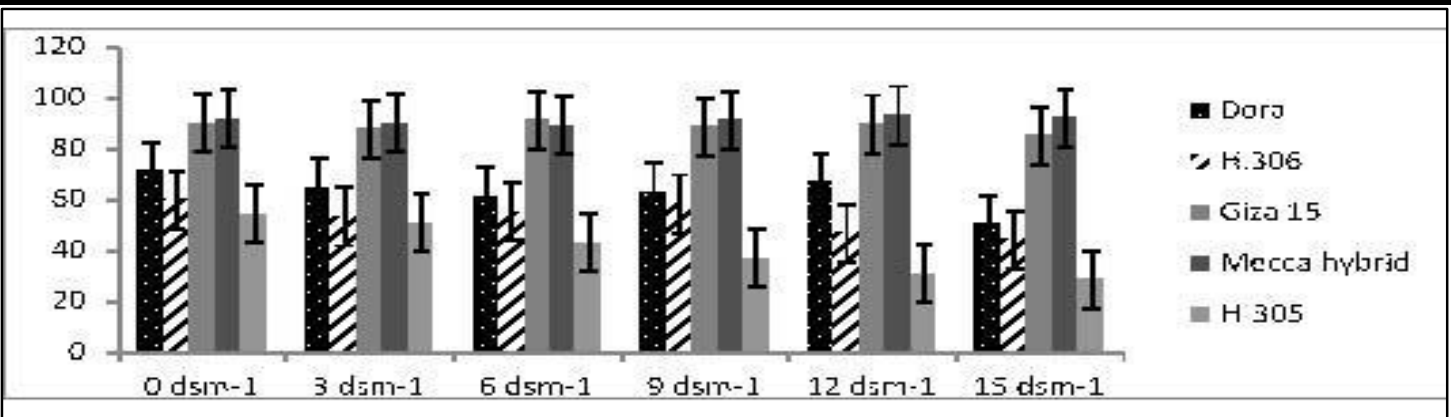

Fig. 11: Average of germination percentage as influenced by studied sorghum cultivars and salinity levels.

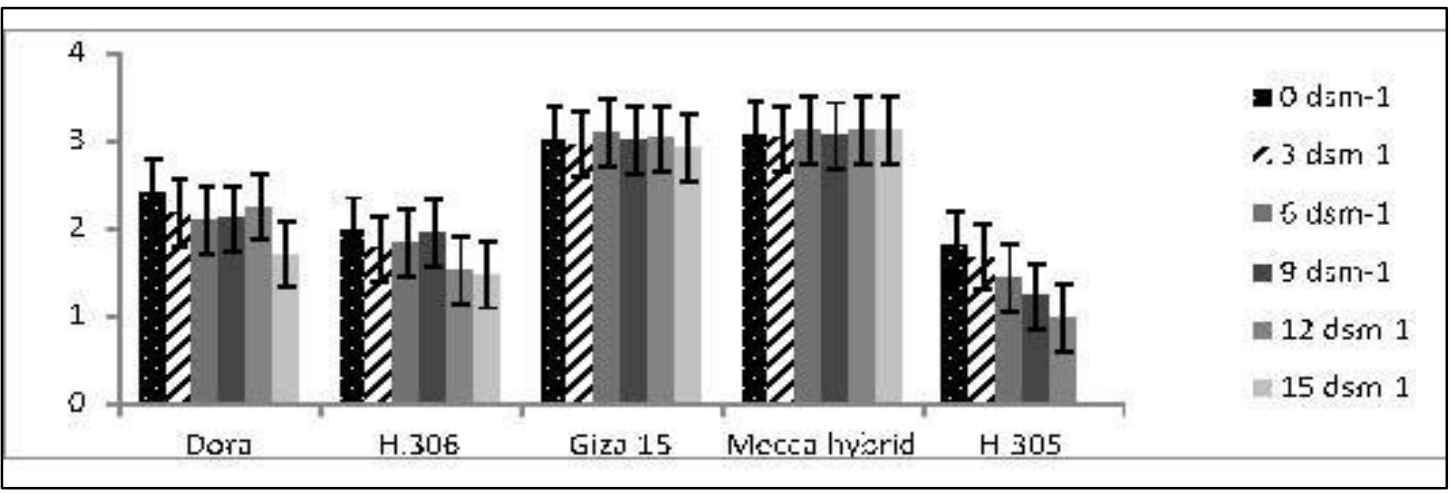

Fig.12: Average of germination rate as affected by studied sorghum cultivars and salinity levels.

3.4.4. Interaction between humic acid soaking $x$ cultivars $x$ salinity levels effects:

The outcomes of statistical analysis was presented indicated that the interaction between humic acid soaking $\mathrm{x}$ cultivars $\mathrm{x}$ salinity levels insignificantly influencedall studied germination parameters and chlorophyll content.

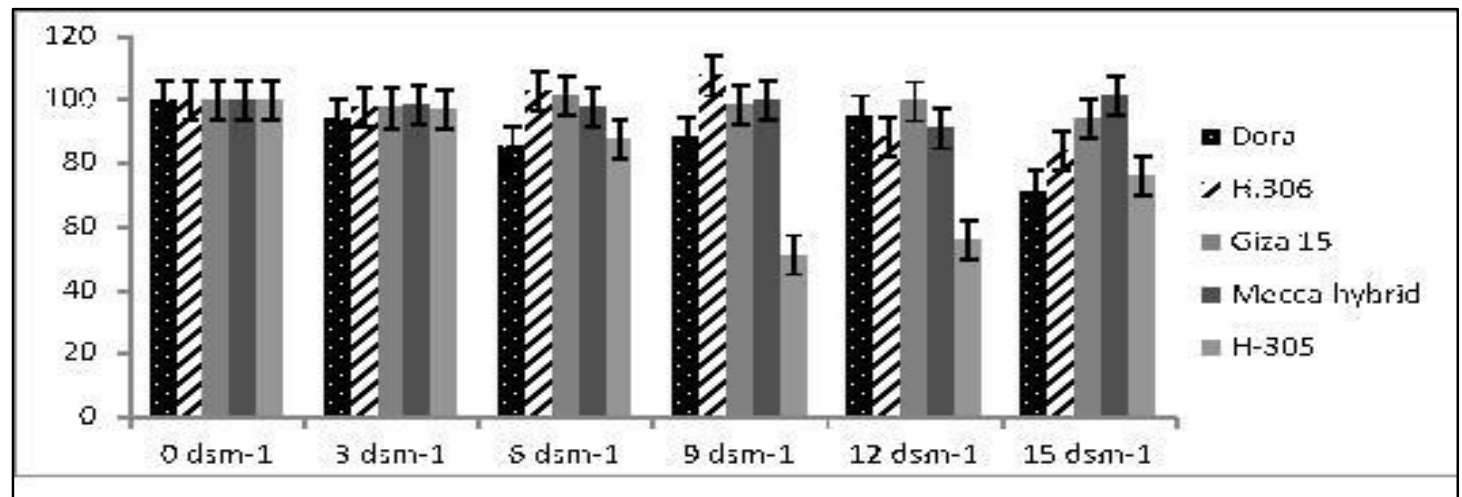

Fig.13: Average of germination index as influenced by studied sorghum cultivars and salinity levels.

\section{CONCLUSION}

It could recommended that soaking sorghum seed of Meeca hybrid with humic acid for $12 \mathrm{~h}$ under salinity of concentration of $6 \mathrm{dSm}^{-1}$ enhanced germination characters compared with other cultivars and salinity concentrations, it mean cultivated it under reclaimed saline soil in Egypt.

\section{REFERENCES}

[1] Abdel-Baki, A. A. and J.D. Anderson 1970. Viability and leaching of sugars from germinating barley. Crops Science, 10: $31 \quad-$ 34.https://www.cabdirect.org/cabdirect/abstract/197 $\underline{01703154}$
[2] Ahmed, S. 2009. Effect of soil salinity on the yield and yield components of Mungbean. Pakistan J. Bot., 4(1):263-268.

http://www.pakbs.org/pjbot/PDFs/41(1)/PJB41(1)26 3.pdf

[3] Aishah, H. S., A. R. Saberi, R. A. Halim and A. R. Zahara 2010. Salinity Effects on Germination on Forage Sorghum. Journal of Agronomy 9(4): 169174. DOI:10.3923/ja.2010.169.174

[4] Almodares, A., M. R. Hadi, B. Kholdibarien, B. Samedani and Z. A. Kharazian 2014. The Response of Sweet Sorghum Cultivars to Salt Stress and Accumulation of $\mathrm{Na}^{+}, \mathrm{Cl}^{-}, \mathrm{K}^{+}$ions in relation to 
Salinity. Journal of Environmental Biology, 35:733739. https://www.ncbi.nlm.nih.gov/pubmed/25004761

[5] Almodares, A., M.R. Hadi and B. Dosti 2007. Effect of Salt Stress on Germination Percentage and Seedling Growth in Sweet Sorghum Cultivars. J. of Biological Sciences, 7(8): 1492-1495. http://scialert.net/abstract/?doi=jbs.2007.1492.1495

[6] Ali, M.A., K. Jabran, S.I. Awan, A. Abbas, M. Ehsanullah, Zulkiffal, T. Acet, J. Farooq and A. Rehman 2011: Morpho-physiological diversity and its implications for improving drought tolerance in grain sorghum at different growth stages. Australian Journal of Crop Science 5(3): 311320.http://www.cropj.com/ali_5_3_2011_311_320.p df

[7] Ali, H., Y. Akbar, Dr. Abdul Razaq and D. Muhammad 2014. Effect of humic acid on root elongation and percent seed germination of wheat seeds. International Journal of Agriculture and Crop Sciences, 7(4): 196-201.http://ijagcs.com/wpcontent/uploads/2014/04/196-201.pdf

[8] Asenjo, M.C., J.L. Gonzales and J.M. Maldonado, 2000. Influence of humic extracts on germination and growth of ryegrass. Communications Soil Sci. Plant Anal., 31: 101114.https://www.tib.eu/de/suchen/id/BLSE\%3ARN0 74687957/Influence-of-Humic-Extracts-onGermination-and/

[9] Asfaw, K.G. 2011. Effects of Salinity on Seedling Biomass Production and Relative Water Content of Twenty Sorghum (Sorghum biolor L. Moench) Accessions. Asian Journal of Agricultural Sciences, 3(3):

242-249.

https://www.medwelljournals.com/abstract/?doi=rja gr.2010.24.30

[10]Behzadnejad, J. and E. Tohidinejad 2014. Ameliorative Effects of Exogenous SA on Germination of Sorghum under Salinity Stress. Journal of Applied Science and Agriculture, 9(4): 1519-1524. www.aensiweb.com/jasa/index.html

[11] Çavuşoğlu, K. and H.G. Ergin 2015. Effects of humic acid pretreatment on some physiological and anatomical parameters of barley (Hordeumvulgare 1.) Exposed to salt stress. Bangladesh J. Bot. 44(4): $591-$

598.http://www.bdbotsociety.org/journal/journal_iss ue/2015\%20December/14.pdf

[12] Chauhan, R. R., C. Reema, S. Alka and P.K. Singh 2012. Salt Tolerance of Sorghum bicolor Cultivars during Germination and Seedling Growth. Research Journal of Recent Sciences, 1(3):2-10. http://www.isca.in/rjrs/archive/v1/i3/1.ISCA-RJRS2012-033 Done.pdf
[13]Dadar, A., A. Asgharzade, and M. Nazari 2014. Investigation effects of different salinity levels on sorghum Bicolor seed germination characters. Indian J. $\quad$ Sci. $\quad$ Res. $7 \quad$ (1): 1031 1034.https://www.ijsr.in/upload/1819321125Micros oft\%20Word\%20-\%20Dadar\%20et\%20al.pdf

[14]De oliveir, A. B. and E. Gomes-Filho 2009. Germination and Vigor of Sorghum Seeds Under Water and Salt Stress. RevistaBrasileira de Sementes, 31(3):.048-056. http://www.scielo.br/scielo.php?script=sci_arttext\& pid=S0101-31222009000300005

[15]Ellis, R.A. and E.H. Roberts 1981. The quantification of ageing and survival in orthodox seeds. Seed Sci. Technol., 9: 373409.http://agris.fao.org/agrissearch/search.do?recordID=XE8182678

[16] El-Naim, A.M., K. E. Mohammed, E. A. Ibrahim and N. N. Suleiman 2012. Impact of Salinity on Seed Germination and Early Seedling Growth of Three Sorghum (Sorghum biolor L. Moench) Cultivars. Science and Technology, 2(2): 16-20. http://article.sapub.org/10.5923.j.scit.20120202.03.h $\underline{\mathrm{tml}}$

[17] Geressu, K. and M. Gezahagne, 2008. Response of some lowland growing sorghum (Sorghum bicolor L. Moench) accessions to salt stress during germination and seedling growth. African Journal Agriculture Research, 3(1): 044-048. http://www.academicjournals.org/article/article1380 877252_Geressu\%20and\%20Gezaghegne.pdf

[18] Gomez, K.A. and A.A. Gomez 1991. Statistical Procedures in Agricultural Research, John Wiley and Sons, New York 2nd edition, pp. 680.http://pdf.usaid.gov/pdf_docs/PNAAR208.pdf

[19]Hefny, M.M., E. M. R. Metwali and A. I. Mohamed 2013. Assessment of genetic diversity of sorghum (Sorghum bicolor L. Moench) genotypes under saline irrigation water based on some selection indices. Australian Journal of Crop Science, 7(12): 1935-1945.

http://www.cropj.com/henfy 7 _ 12_2013_1935_194 $\underline{5 . p d f}$

http://agris.fao.org/agrissearch/search.do?recordID=PK2013000980

[20]Hussain, S. H, A. Khaliq, A. Matloop, W.M. Ashfaq and I. Afzal 2013. Germination and growth response of three wheat cultivars to $\mathrm{NaCl}$ salinity.Soil \& Environment, 32(1): 36-43.http://agris.fao.org/agrissearch/search.do?recordID=PK2013000980

[21]ISTA Rules. (2013). Germination Sec. Chapter 5: pp. $5-44$.

[22] Jamil, M., D.B. Lee, K.Y. Jung, M. Ashraf, S.C. Lee and S.E. Rha 2006. Effect of salt $(\mathrm{NaCl})$ stress on 
germination and early seedling growth of four Vegetable species.Journal Central European Agriculture, 7(2): 273282.https://jcea.agr.hr/articles/358_EFFECT_OF_S ALT_(NACL)_STRESS_ON_GERMINATION_A ND_EARLY_SEEDLING_GROWTH_OF_FOUR VEGETABLES_SPECIES en.pdf

[23] Jajarmi, V. 2007. Effects of Water Stress on Germination Indices in Ten Rapeseed Cultivars (Brassica napus L.). Abstracts, The Second Seminar of Agriculture and Environment. Islamic Azad University, Khoy Branch, Iran. https://www.anau.am/images/stories/journal/4_2008/ Ag_4_2008/11-14_4_2008.pdf

[24] Kandil A.A., A.E. Sharief, W.A.E. Abido and M.M. Ibrahim 2012. Effect of Salinity on Seed Germination and Seedling Characters of Some Forage Sorghum Cultivars. International Journal of Agriculture Sciences, 4(7): 306311.http://oaji.net/articles/2014/30-1394266790.pdf

[25] Karim, M. A.; N. Utsunomiya and S. Shigenaga 1992. Effect of sodium chloride on germination and growth of hexaploid triticale at early seedling stage. Japanese Journal of Crop Science,61: 279 284.https://www.jstage.jst.go.jp/article/jcs1927/61/2 /61_2_279/_article

[26] Kausar, A., M. Y. Ashraf, I. Ali, M. Niaz and Q. Abbass 2012. Evaluation of sorghum varieties/lines for salt tolerance using Physiological indices as screening tool. Pak. J. Bot., 44(1): 4752.https://inis.iaea.org/search/search.aspx?orig_q=R $\mathrm{N}: 43028062$

[27] Khan, A., M. Ibrar and I. Ahmad 2014. A preliminary approach to halo sensitivity of sorghum cultivars. African Journal of Plant Science, 8(1): 7683.http://www.academicjournals.org/journal/AJPS/a rticle-full-text-pdf/761A51342821

[28] Mohammadi, N. and M. Mojaddam 2014. The Effect of Water Deficit Stress on Germination Components of Grain Sorghum Cultivars. Indian Journal of Fundamental and Applied Life Sciences, 4(4): $\quad$ 284-291.http://www.cibtech.org/J-LIFESCIENCES/PUBLICATIONS/2014/Vol-4-No4/JLS-043-046-MANI-EFFECT-CULTIVARS.pdf

[29] Munns, R., James, R.A. and A. Lauchli 2006. Approaches to increasing the salt tolerance of wheat and other cereals. J. Exp. Bot., 57: 1025-1043. https://www.ncbi.nlm.nih.gov/pubmed/16510517

[30] Nazi, F., H. Reza and R. Rahman 2014. Effect of Humic Fertilizer on Germination of Wheat Seeds under Drought Stress. Advances in Bioresearch 5(4): 98-102. http://soeagra.com/abr/abrdec2014/18.pdf

[31] Noreen, S. and M. Ashraf 2008. Alleviation of adverse effects of salt stress on sunflower
(Helianthus annuus L.) by exogenous application of salicylic acid: Growth and photo-synthesis. Pakistan Journal Botany, 40(4): 1657-1663. http://sa.indiaenvironmentportal.org.in/files/Pakistan \%20Journal.pdf

[32]Ruan, S., Q. Xue and K. Tylkowsko 2002. The influence of priming on germination of rice (oryza sativa L.) seeds and seedling emergence and in flooded performance soils. Seed Sci. Technil., 30: $61-67$.

https://www.scienceopen.com/document?vid=d0879 887-4833-4f80-b5a8-3fefaac5c7c7

[33] Russell, D.F. 1986. MSTAT-C computer based data analysis software Crop and Soil Science Department, Michigan State University USA.https://msu.edu/ freed/disks.htm

[34] Sam, A., A. Y. Edris and M.S.A. Abo 2014. Effect of Salinity on Seed Germination and Seedling Growth of Pearl millet (Pennisetumglaucum L.) and Sorghum (Sorghum bicolor L.), Journal of Plant and Pest Science, $1 \quad$ (1): 01-08. http://journals.sfu.ca/jpps/index.php/jpps/article/vie wFile/4/10

[35] Saroj, M. and D. Soumana, 2014. Salt stress induced changes in growth of germinating seeds of Vigna mungo(L.) Hepper and Vigna aconitifolia (Jacq.) Marechal. IOSR Journal of Agriculture and Veterinary Science, $7 . \quad$ (4):44-48. http://www.recentscientific.com/sites/default/files/4 336.pdf

[36] Sawamery, N. and M. Mojaddam 2014. The Effect of Salinity Stress on Germination Components of Grain Sorghum Cultivars. Indian Journal of Fundamental and Applied Life Sciences, 4(4): 431$437 . \quad$ http://www.cibtech.org/J-LIFESCIENCES/PUBLICATIONS/2014/Vol-4-No4/JLS-063-66-DEC-ACCEPT-MANI-THECULTIVARS.pdf

[37] Siddig, A.A.M. and A.A.Y. Idris 2015. Response of Sorghum (Sorghum bicolor L.) Cultivars to Salinity Levels at Early Growth Stages. J. of Agricultural Science and Engineering, 1(1): 11-16. http://www.publicscienceframework.org/journal/jase

[38] Snedecor GW and WG. Cochran 1980. Statistical Methods. $7^{\text {Th }}$ Ed. Iowa State University Press, Iowa, USA, ISBN-10: 0-81381560-6, Pp: 507. https://www.amazon.com/Statistical-MethodsSeventh-isbn-0813815606/dp/B0012S4NIE

[39] Sun, Y., G. Niu1, P. Osuna, L. Zhao, G. Ganjegunte, G. Peterson, J. R. Peralta-Videa, and J. L. GardeaTorresdey 2014. Variability in Salt Tolerance of Sorghum bicolor L. Agricultural Science, 2(1): 9-21. www.iosrjournals.orgwww.iosrjournals.org 
[40] Tabatabaei, S. A., and A. Anagholi 2012. Effects of salinity on some characteristics of forage sorghum genotypes at germination stage. International Journal of Agriculture and Crop Sciences, 4(14): 979983.http://ijagcs.com/wpcontent/uploads/2012/09/979-983.pdf

[41] Tigabo, E., M. Andargie and K. Tesfaye 2013. Genotypic Variation for Salinity Tolerance in Sorghum (Sorghum bicolor (L.) Moench) Genotypes at Early Growth Stages. Journal of Stress Physiology $\begin{array}{llll}\text { \& Biochemistry, } & 9 & \text { (2): } \quad 253-262 .\end{array}$ http://cyberleninka.ru/article/n/genotypic-variationfor-salinity-tolerance-in-sorghum-sorghum-bicolorl-moench-genotypes-at-early-growth-stages

[42]Zafar, S., M. Y. Ashraf, M. Niaz1, A. Kausar and J. Hussain 2015. Evaluation of wheat genotypes for salinity tolerance using Physiological indices as screening tool. Pakistan J. Botany, 47(2): 397405.https://www.pakbs.org/pjbot/PDFs/47(2)/02.pdf

[43] Wei G. and W. Qing-Xiang 2011. Effects of seed soaking with humic acid on wheat seedlings antioxidant system under salt-alkali stress. YingyongShengtaiXuebao, $22 \quad$ (10):2539. http://connection.ebscohost.com/c/articles/69910778 leffects-seed-soaking-humic-acid-wheat-seedlingsantioxidant-system-under-saltalkali-stress 